\title{
KOMUNIKASI ANTAR AKTIVIS ORGANISASI KEMASYARAKATAN NAHDLATUL ULAMA' DAN MUHAMMADIYAH DI DESA CANGAÁN KECAMATAN KANOR KABUPATEN BOJONEGORO
}

\author{
M. Fakhrul Irfan Syah, Luluk Fikri Zuhriyah \\ Email:_ahirfansyah@gmail.com,lulukfikri@uinsby.ac.id \\ Komunikasi Penyiaran Islam, UIN Sunan Ampel, Surabaya \\ Jl. Jend. A. Yani 117 Surabaya 60237 \\ Submitted: 19 Februari 2021 | Accepted: 24 Maret 2021 | Published: 30 Juni 2021 \\ Website: https://e-journal.umc.ac.id/index.php/jike/index
}

\begin{abstract}
The problems studied in this study are the pattern of interpersonal communication in Canga'an village, Kanor sub-district, Bojonegoro district as well as the things behind the communication between activists of Nahdlatul Ulama' and Muhammadiyah social organizations in Canga'an Village. The method used is descriptive qualitative method. with data collection techniques of observation, interviews, and documentation. The theory used is Erving Goffman's dramaturgical theory to see the phenomena that occur in the communication of Nahdlatul Ulama' and Muhammadiyah' social organizations in Canga'an village related to the concept of front stage and back stage through interpersonal communication patterns of organizational actors. From the results of this study, there are 2 (two) research findings: First, communication between organizational activists in Canga'an village, Kanor sub-district, Bojonegoro district is good, the indicators used by researchers in assessing communication between organizational activists are dynamic or not. Second, the emergence of communication between activists of community organizations is motivated by historical factors other than an organized social ego and also a sense of belonging to community organizations to make Nahdlatul Ulama' and Muhammadiyah a support system for organizers of Nahdlatul Ulama' and Muhammadiyah' social organizations.
\end{abstract}

Keywords: Communication, Organization, Nahdlatul Ulama', Muhammadiyah.

\begin{abstract}
Abstrak
Permasalahan yang dikaji dalam penelitian ini yaitu pola komunikasi antar pribadi di desa Canga'an kecamatan Kanor kabupaten Bojonegoro serta hal-hal yang melatar belakangi komunikasi antar aktivis organisasi kemasyarakatan Nahdlatul Ulama' dan Muhammadiyah di Desa Canga'an.Metode yang digunakan adalah metode deskriptif kualitatif dengan teknik pengumpulan data observasi, wawancara, dan dokumentasi. Teori yang digunakan adalah teori dramaturgi Erving Goffman untuk melihat fenomena yang terjadi padakomunikasi organisasi kemasyarakatan Nahdlatul Ulama' dan Muhammadiyah di desa Canga'an terkait dengan konsep front stage dan back stage melalui pola komunikasi antar pribadi pelaku organisasi. Dari hasil penelitian ini ada 2 (dua) temuan penelitian: Pertama, komunikasi antar aktivis organisasi di desa Canga'an kecamatan Kanor kabupaten Bojonegoro baik, indikator yang digunakan peneliti dalam menilai komunikasi antar aktivis organisasi yakni dinamis atau tidaknya komunikasi. Kedua, munculnya komunikasi antar aktivis organisasi kemasyarakatan di latar belakangi oleh faktor sejarah selain itu ego sosial yang terorganisir dan juga rasa memiliki terhadap organisasi kemasyarakatan hingga membuat Nahdlatul Ulama' dan Muhammadiyah menjadi support system bagi organisator organisasi kemasyarakatan Nahdlatul Ulama' dan Muhammadiyah.
\end{abstract}

Kata Kunci :Komunikasi, Organisasi, Nahdlatul Ulama', Muhammadiyah.

\section{A. PENDAHULUAN}

Indonesia dalam kehidupan beragama, enam agama yang legal di indonesia yakni: Islam, Kristen, kahtolik, Konghucu, Budha dan Hindu. Selain perbedaan tersebut ada beberapa hal yang perlu diperhatikan. Dalam agama islam masih terdapat perbedan terutama di wilayah Jawa, di wilayah Jawa masih terkandung potensi permusuhan yang 
luar biasa. Yakni orang Jawa yang menganut agama Islam dengan ketat seperti yang termaktub dalam syariat islam. Orang Jawa yang menganut agama islam sinkretik, yaitu agama Islam yang terkontaminasi dengan unsur-unsur agama Budha, Hindu dan roh nenek moyang. ${ }^{1}$

Lebih lanjut Koentjaraningrat menguraikan:

Para penganut agama Islam yang pertama, yang taqwa dan patuh menjalankan shalat lima kali sehari, yang secara teratur pergi ke masjid dan tiap hari jumat siang, yang secara patuh menjalankan puasa tiap bulan Ramadhan dan patuh memyumbangkan zakat fitrahnya pada waktu-waktu yang telah diharuskan oleh syariah, yang bercita-cita menjalankan kewajiban naik haji kalau mereka mampu dan pantang memakan daging babi, oleh orang Jawa sendiri disebut orang "santri". Adapun agama Islam dijawa yang para penganutnya tak pernah menjalankan kewajiban-kewajiban tersebut tetapi mempunyai konsep lain tentang agama dan melaksanakan upacara-upacara keagamaan yang lain, oleh orang jawa sendiri disebut agama "Islam Jawa" (atau agama Kejawen) atau kadang-kadang juga disebut orang "abangan".

Akhir-akhir ini suasana keagamaan di Indonesia terasa agak merisaukan. Saya sebutkan agak saja agar tidak menjadi preseden bahwa kehidupan beragama di Indonesia sedang bermasalah. Ada tiga hal yang kiranya perlu untuk dicermati terkait dengan kehidupan beragama kita, yaitu: pertama, semakin mengerasnya tekanan untuk memiliki pemahaman agama yang monolitik. Harus ada tafsir tunggal mengenai agama tersebut. Tidak boleh ada penafsiran lain yang berbeda dengan tafsir yang dikembangkan. Misalnya dengan semakin menguatnya beberapa aliran keagamaan yang cenderung untuk hanya membenarkan tafsir agamanya sendiri dan yang lain harus disalahkan. Bahkan yang lebih keras menyatakan bahwa faham keagamaan yang tidak sesuai dengan faham agamanya dianggap sebagai kafir.

Masyarakat Indonesia dikenal dikenal sebagai masyarakat yang religius dan mengedepankan beragama yang moderat. Masyarakat Islam Indonesia itu terkenal dengan sikap tawazun, tawassuth, dan tasamuh. Masyarakat yang beragama dengan jalan tengah, yang moderat dan toleran. Makanya, dikala di belahan Timur Tengah terjadi perebutan kekuasaan dengan cara kekerasan dan pemaksaan, maka sesungguhnya hal ini bukanlah ciri khas masyarakat Indonesia.

Beragama dengan memahami teks dan konteks, memahami sosiokultural dan sosioekonomi pada setiap gerakan yang terjadi menjadi penting untuk dilakukan. Dengan demikian setiap pikiran dan tindakan membela Islam harus ditimbang dari berbagai sudut

\footnotetext{
${ }^{1}$ Koentjaraningrat, Masalah-masalah pembangunan (Jakarta: LP3ES, 1982) 355
} 
dan sisi, sehingga kita akan bisa memahaminya sebagai suatu keharusan, atau tidak. ${ }^{2}$ Masing-masing kelompok dalam pengorganisasian turut mempengaruhi terhadap muncunya segmentasi maupun perpecahan dalam tubuh masyarakat di dalam satu pihak. Namun dipihak lain juga berperan sebagai tenaga pendorong atas terwujudnya integrasi dalam interaksi sosial masyarakat tersebut. Konflik tersebut tercipta dan menjadi pusat kompetisi kepemimpinan dalam berbagai organisasi-organisasi yang terdapat pimpinan dan pendukung organisasi tersebut dalam menghadapi, menginterpretasi dan beradaptasi satu dengan yang lain serta menggunakan konten-konten syariat agama Islam yang diketahuinya dalam menginternalisasi tindakan dalam menjalankan aktivitas lingkunganya. ${ }^{3}$

Ada dua organisasi Islam besar yang dianngap mewakili muslim santri di Indonesia, Nahdlatul Ulama' (NU) yang sering kali dianggap mewakili sebagai golongan tradisionalis dan Muhammadiyah yang dianggap mewakili golongan modernis, NU adalah organisasi ulama' tradisional yang tidak bisa dilepaskan dari keberadaan pesantren, mengingat sebagian besar pendiri dan pendukung utamanya adalah para kiai yang berasal dari dan memimpin pesantren. ${ }^{4}$

Organisasi kemasyarakatan memegang peranan yang sangat penting dalam suatu tatanan masyarakat, termasuk di desa Canga'an kecamatan Kanor kabupaten Bojonegoro dimana ada dua Organisasi kemasyarakatan besar yang berkembang pesat yakni Nahdlatul Ulama' dan Muhammadiyah, warna persaingan Organisasi kemasyarakatan menjadi wadah yang sangat penting dalam pembentukan karakter organisator dalam memperbaiki karakter untuk menjadi generasi penerus yang berkemajuan.

Komunikasi antar aktivis organisasi mulai dari tingkatan pusat hingga tingkatan daerah menjadi suatu fenomena menarik dalam interaksi sosial. Aktivitas yang dijalankan oleh organisasi-organisasi kemasyarakatan tentu menarik perhatian masyarakat setempat, organisasi kemasyarakatan tersebut memiliki arah tujuan, kerjasama dan strategi tersendiri yang menjadi budaya organisasi dalam komunikasi organisasi kemasyarakatan guna memperbaiki keadaan organisasi.

Aktor-aktor dalam Organisasi kemasyarakatan menggunakan berbagai bentuk cara untuk memperbaiki keadaan organisasi, seperti visi, misi, untuk memperoleh kekuasaan.

\footnotetext{
${ }^{2}$ Nur Syam, Islam Nusantara Berkemajuan: Tantangan dan Upaya Moderasi Agama (Semarang: Fatwa Publishing, 2018) hal. 3-4.

${ }^{3}$ Achmad Fedyani Saefudin, Konflik dan Integrasi: Perbedaan Faham dalam Agama Islam (Jakarta: CV Rajawali, 1986) 99.

${ }^{4}$ Djohan Effendi, Pembaruan Tampa Membongkar Tradis: Wacana Keagamaan di Kalangan Muda NU Masa Kepemimpinan Gus Dur (Jakarta: Kompas, 2010) 1.
} 
Beberapa hal yang terkait dalam komunikasi Organisasi kemasyarakatan diantaranya ialah interaksi sosial. Dalam proses komunikasi, politik memegang peranan penting didalam masyarakat. Menurut Harold Lasswell dalam karya Ramlan Surbakti, Politik digambarkan sebagai siapa mendapatkan apa, kapan, dan bagaimana. Jadi politik digambarkan sebagai sebuah seni dalam mempengaruhi orang lain dalam artian masyarakat menjadi followers untuk memperoleh sesuatu menggunakan berbagai cara dan strategi yang diinginkan. ${ }^{5}$

Peran agama juga teramat penting dalam mengawal komunikasi antar aktivis organisasi. Hal tersebut dituangkan dalam bentuk ideologi bangsa Indonesia, yakni Pancasila: "KeTuhanan Yang Maha Esa". Agama di Indonesia memiliki fungsi secara kolektif untuk memperbaiki pola komunikasi antar aktivis organisasi.

Dituangkan pula dalam Undang-Undang Dasar Negara Republik Indonesia tahun 1945 bahwa :"tiap-tiap penduduk diberikan kebebasan untuk memilih dan mempraktikkan kepercayaannya, dan menjamin semuanya akan kebebasan untuk menyembah, menurut agama atau kepercayaanya". Lebih dari itu, kepemimpinan politis di desa Canga'an kecamatan Kanor kabupaten Bojonegoro juga tidak terlepas dari peranan NahdlatulUlama' dan Muhammadiyah. Dalam kehidupan masyarakat di desa Canga'an kecamatan Kanor kabupaten Bojonegoro komunikasi antar aktivis Organisasi kemasyarakatan seakan-akan sudah mendarah daging dalam aspek politis. Organisasi kemasyarakatan di Desa Canga'an kecamatan Kanor kabupaten Bojonegoro merupakan bagian simbol identitas politik dan agama yang membawa makna besar. Yang disampaikan dari simbol tersebut, politik dan agama dapat mengikat emosi anggota Organisasi kemasyarakatan.

Dalam penelitian ini, peneliti bertujuan untuk mengkaji komunikasi antar aktivis organisasi kemasyarakatan di desa Canga'an kecamatan Kanor kabupaten Bojonegoro dalam komunikasi organisasi kemasyarakatan termasuk dalam lingkaran politik dan agama di desa Canga' an kecamatan Kanor kabupaten Bojonegoro, karena memang ada kemunginan besar bahwa keberadaan dua organisasi kemasyarakatan besar (Nahdlatul Ulama' dan Muhammadiyah) digunakan masyarakat sebagai tunggangan dalam komunikasi antar aktivis organisasi.

\section{B. TINJAUAN PUSTAKA}

\section{Sejarah Gerakan Organisasi Kemasyarakatan}

Dari aspek sejarah, gerakan keagamaan merupakan konsequensi logis dari kelahiran

\footnotetext{
${ }^{5}$ Ramlan Surbakti, Memahami Ilmu Politik (Jakarta :PT. Grasindo, 1992) hal.4
} 
ormas-ormas Islam sejak abad ke-19. Serta perkembangannya dewasa ini, secara umum, periodisasi perkembangan ini dibagi atas tiga tahap. Yang pertama periode mitos, periode ideologi, dan periode ilmu/ide. Periodisasi tersebut ada berdasar pada pengetahuan sosiologi yang melihat kesadaran bentuk-bentuk umat agama Islam pada suatu waktu. Dalam periode mitos, kepercayaan umat islam masih bersifat religious mistis, sehingga sifat mitos mewarnai waktu itu. Mitos tersebut concern pada keyakinan akan kehadiran Ratu Adil. Ratu Adil dianggap dapat melepaskan belenggu kemiskinan umat islam yang di akibatkan dari derita penjajahan. Umat Islam sangat menantikan kelahiran suatu dinasti otupia, akan tetapi umat islam tidak mengetahui cara menuju ke sana. Serta tidak mengetahui langkah yang hendak akan ditempuh. Periode ini kira-kira berlangsung tahun 1900.

Periode setelah itu, khazanah ilmu pengetahuan dalam agama islam dianggap bagaikan faktor yang berpegang teguh pada norma. Hingga perkembanganya pesat menjadi sistim ideologi yang bermuara pada aksi. Pada fase ini disebut sebagai periode ideologi yang berlangsung kira-kira hingga tahun 1965, meskipun bukan batas waktu yang jelas. Pada masa selanjutnya terjadi pada pasca 65-an yang ditandai dengan tumbangnya PKI.

Perkembangan pada Negara ini mulai tergerus pada periodisasi ilmu karena sistem rasional pada masa ini mulai diperjuangkan dan tidak lagi mengenakan sistem Negara ideal. Yang mengalami ekspansi pada periode ini ialah pada bidang sosial, yang sangat berbeda dengan periode ideologi yang diperjuangkan pada bidang politik. Melihat fenomena tersebut dapat diketahui bahwa organisasi kemasyarakatan islam mulai ada pada saat periode ideologi. Selain itu faktor internasional juga turut berperan bagi kelahiran organisasi kemasyarakatan. Karena islam di Negara timur tengah cukup massif. Namun, dinamika internal umat juga merupakan aktor yang dominan dari abad lalu sampai saat ini. ${ }^{6}$

\section{Macam-macamOrganisasi Masyarakat}

Macam-macam organisasi kemasyarakatan cukup beragam, namun pada dasarnya hanya dikelompokkan dalam dua kelompok. Yakni: 1) Yang pertama, organisasi kemasyarakatan yang khusus bergerak pada satu bidang. Biasanya organisasi kemasyarakatan yang menggeluti suatu bidang pada profesi tertentu yang masuk pada kelompok ini. Misal, Himpunan Nelayan Seluruh Indonesia (HNSI), Asosiasi Pedagang Pasar Seluruh Indonesia (APPSI), Himpunan Kerukunan Tani Indonesia (HKTI), Ikatan Dokter Indonesia (IDI),

\footnotetext{
${ }^{6}$ Soedirman Tebba, “Ormas Islam dan Dilema Pembaharua," dalam Islam Indonesia Menatap Masa Depan (Jakarta: P3M, 1989), 228
} 
Ikatan Ahli Geologi Indonesia (IAGI), Persatuan Insinyur Indonesia (PII), Persatuan Advokat Indonesia (Peradin), Asosiasi Persatuan Sarjana Hukum Indonesia (APHI), dan lain sebagainya. 2) Selain itu, ada pula organisasi kemasyarakatan yang menekuni kegiatan dalam bidang kemasyarakatan yang mencakup lebih dari satu bidang. semisal: Muhammadiyah, Nahdlatul Ulama', HKBP, Persis, dan lain sebagainya. Dalam praktiknya di tengah masyarakat organisasi kemsyarakatan ini tidak hanya bergerak pada satu bidang saja yang di geluti. Akan tetapi, ada bidang lain yang digeluti. Semisal : selain bergerak dibidang dakwah dan kemasyarakatan juga bergerak dibidang pendidikan, kesehatan dan kegiatan sosial lainya. ${ }^{7}$

\section{Peran dan Tanggung Jawab Organisasi Kemasyarakatan dalam menjaga Pola Komunikasi Antar Pribadi}

Segala aspek kehidupan saat ini sudah dipermudah oleh revolusi industri yang sampai detik ini selalu memberikan warna baru dalam komunikasi. Terkhusus bidang teknologi, bukti nyatanya saat ini Jarak suatu Negara ke Negara yang lain pun tidak menghalangi manusia untuk melaksanakan mobilisasi dalam komunikasi. Kemajuan teknologi di bidang telekomunikasi tidak hanya dapat dinikmati oleh Negara secara kelembagaan, akan tetapi masing-masing pribadi individu juga bisa menikmatinya. Fenomena ini selain memberikan dampak positif yang luar biasa disisi lain juga mengakibatkan pergeseran pola kebudayaan dalam suatu masyarakat.

Kemudahan yang ditawarkan telekomunikasi yang bisa diakses oleh individu dibeberapa Negara sedikit banyak turut andil dalam pergeseran paradigma berfikir masyarakat. Yakni semakin meningkatnya tuntutan akan hak-hak individu dalam masyarakat. Yang sebelumnya hanya memiliki hak untuk mendapatkan kesejahteran secara lahiriah. Saat ini sudah meningkat menjadi hak-hak yang lebih luas. Salah satu contohnya hak untuk berekspresi dalam berkomunikasi antar pribadi.

Semakin terbukanya akses interaksi melalui telekomunikasi yang semakin maju dari Negara satu ke Negara yang lain. Semakin terbuka pula teori zoompoliticon seperti yang dikemukakan Aristoteles. Jika saat itu Aristoteles hanya mengemukakan bahwa manusia adalah mahluk sosial dan memiliki akses yang tak terbatas dalam interaksi sosial dan dalam segmen Negara dan Kota. Akan tetapi tetap memiliki ketrbatasan akses pada ruang lingkup tertentu.

${ }^{7}$ Sondang P. Siagian, Filsafat Administrasi (Jakarta:Gunung Agung, 1980), 68 
Maka dalam konteks zoompoliticon saat ini akses komunikasi individu tidak hanya terbatas pada ruang lingkup tertentu seperti era Aristoteles pada saat masih hidup. Tetapi saat ini cakupan sudah tak terbatas karena adanya kemajuan teknologi komuniasi. Hal tersebut sudah terbukti bahwa dengan adanya kemajuan dibidang telekomunikasi membuat akses interaksi masyarakat dalam interaksi sosial sudah berlangsung antarNegara, antar Agama, antar Budaya, suku hingga menembus tingkatan sosial. Maka dari itu pola komunkasi saat ini tidak bisa dilepaskan dari pengaruh global termasuk komunikasi antar aktivis organisasi kemasyarakatan.

Akibat dari hal ini banyak sekali fenomena-fenomena yang terjadi dan menjadi hal baru dalam suatu komunikasi. Salah satunya kesepakatan-kesepakatan yang merambah dunia internasional, banyak fenomena-fenomena baru yang memberi warna baru dalam komunikasi di aspek politik, ekonomi, budaya dan lain sebagainya. Semisal kesepakatan dalam perdagangan internasional, untuk tidak membatasi arus keluar masuk barang disuatu Negara.

Kenyataan ini secara tidak langsun akan membuat kerugian dibeberapa Negara yang secara teknis masih belum mempunyai kesiapan secara mumpuni dalam mengarungi persaingan di pasar bebas. Hal ini tentunya juga berpengaruh terhadap tingkat kesejahteraan rakyat, khususnya di Indonesia yang beberapa bagian masyarakatnya masih belum siap menghadapi pasar bebas yang terjadi saat ini.

Dengan demikian masalah yang terjadi semakin kompleks, dan masyarakat tentu tidak harus hanya mengandalkan organisasi pemerintahan konvensional untuk menanggulangi masalah ini. Terobosan-terobosan baru dalam tubuh komunikasi sudah harus tercetus dalam tubuh organiasi kemasyarakatan. Salah satu problemsolving yang dapat dimaksimalkan masyarakat ialah potensi yang ada dalam organisasi kemasyarakatan. Karena kecil kemungkinan organisasi pemerintahan bisa menyelesaikan semua masalah yang terjadi dalam komunikasi antar aktivis organisasi.

Baik organisasi pemerintahan maupun organisasi kemasyarakatan harus sama-sama terlibat dalam suatu usaha menjaga komunikasi antar aktivis, baik secara kelembagaan maupun melalui organisator guna menata tanggung jawab yang besar dalam menjaga kondisi interaksi sosial agar tetap stabil. Maka organisasi pemerintahan dan oganisasi kemasyarakatan memiliki tanggung jawab besar dan sentral.

Pembangunan serta pembinaan komunikasi melalui membina kesadaran berbangsa dan bernegara sangatlah penting. Karena keberlangsungan komunikasi antar pribadi salah satunya melalui kehidupan berbangsa dan bernegara. Organisasi kemasyarakatan menjadi 
salah satu ujung tombak pada hal ini, karena hampir sebagian besar penduduk Indonesia menjadi anggota organisasi kemasayrakatan.

Sudah tidak waktunya bagi organiasi kemasyarakatan hanya bergerak pada tataran keagamaan saja. Tetapi sudah waktunya bagi organisasi kemasyarakatan untuk mulai merambah pada sektor garap lainya dan juga persoalan-persoalan kemasyarakatan lain yang mulai tumbuh dalam komunikasi pada umumnya. Sektor garap dan persoalan-persoalan kemasyarakatan yang harus mulai disentuh cukup banyak, diantaranya : 1) Dalam bidang pendidikan, saat ini dikira masih sangat perlu adanya sentuhan-sentuhan dalam bidang pendidikan. Perlunya dimaksimalkan pembangunan pendidikan mulai dari tingkatan pra sekolah (taman kanak-kanak) hingga tingkat perguruan tinggi). ${ }^{8}$ Maka dari itu di era revolusi industri saat ini masing masing elemen yang ada di tubuh masyarakat harus berperan aktif dalam menjaga kestabilan komunikasi. Organisasi pemerintahan tidak akan bisa memaksimalkan potensi kekuatanya tanpa ada dukungan dan dorongan dari organisasi kemasayarakatan. Dari sini sudah terlihat bahwasanya peran dan tanggung jawab organisasi kemasyarakatan sangat vital didalam menjaga kestabilan komunikasi.

\section{Dramaturgi}

Masalah tak terpisahkan dari kehidupan manusia, walaupun manusia merupakan makhluk sosial, tidak dipungkiri akan terjadinya masalah. Kehidupan manuasia dikatakan berhasil, jika mampu dalam menyelesaikan masalahnya. Apabila manusia tidak mampu menyelesaikan atau menghadapi masalahnya, maka orang tersebut telah gagal. Apabila suatu masyarakat semain maju tingkat pemenuan kebutuhanpun semakin meningkat.

Teori dramaturgi ialah pernyataan Erving Goffman (1922-1982) dalam aliran Chicago beliau merupakan pemikir utama terakhir. Bisa dikatakan secara sederhana, Goffman melihat banyak persamaan diantara pertunjukan teatrikal. Serta jenis-jenis “tindakan” yang kita lakukan didalam perbuatan-perbuatan dan interaksi-interaksi kita sehari-hari.

Komunikasi dilihat sangat rapuh, dipelihara oleh pertunjukan sosial. Pertunjukan yang buruk atau kekacauan dilihat sebagai ancaman besar bagi komunikasi sosial persis seperti pertunjukan teatrikal. Goffman menyadari diri bukan milik sang aktor, tetapi lebih tepatnya sebagai produk komunikasi dramatik antara aktor dan audiens. Diri "adalah suatu efek dramatik yang sedang muncul. dari suatu adegan yang disajikan”. Karena diri adalah

${ }^{8}$ Jimly Asshiddiqie,Perkembangan dan KonsolidasiLembaga Negara Pasca-Reformasi (Jakarta:Konstitusi Press,2006), 7 
suatu produk komunikasi dramatik, diri rapuh terhadap kekacauan yang terjadi selama berlangsungnya sandiwara.

Para aktor berharap bahwa pengertian diri yang mereka sajikan kepada audiens akan cukup kuat. Cukup kuat bagi audiens untuk mendefinisikan para aktor seperti yang diinginkan para aktor itu. Para aktor juga berharap bahwa hal itu akan menyebabkan audiens bertindak dengan sengaja seperti yang diinginkan para aktor. Goffman mencirikan perhatian sentral tersebut sebagai "manajemen kesan". Hal itu meliputi teknik-teknik yang digunakan para aktor untuk memelihara kesan-kesan tertentu. Dalam menghadapi masalah-masalah yang mungkin mereka jumpai dan metode-metode yang mereka gunakan untuk mengatasi masalah-masalah tersebut.

Mengikuti analogi teatrikal demikian, Goffman membahas mengenai panggung depan (front stage). Bagian depan adalah bagian dari sandiwara yang secara umum berfungsi dengan cara-cara yang agak baku dan umum. Untuk mendefinisikan situasi bagi orang-orang yang mengamati sandiwara itu. Didalam panggung depan, Goffman membedakan lebih lanjut bagian depan latar (setting front) dan bagian depan-pribadi (personal). Latar mengacu kepada tempat atau situasi (scene) fisik yang biasanya harus ada jika para aktor hendak bersandiwara. Tanpa itu, para aktor biasanya tidak dapat melakukan sandiwara.

Meskipun Goffman mendekati bagian depan dan aspek-aspek lain sistemnya sebagai seorang interaksionis simbolik. dia benar-benar mendiskusikan karakter stukturalnya. Contohnya, dia berargumen bahwa bagian depan cenderung menjadi terlembaga, dan begitu juga “representasi kolektif” muncul di sekitar apa yang sedang berlangsung di dalam suatu bagian depan tertentu. Seringkali ketika para aktor mengambil peran-peran yang sudah mapan, mereka menemukan bagian depan tertentu sudah mapan untuk sandiwara demikian. Hasilnya Goffman berargumen, ialah bagian depan itu cenderung di seleksi, bukan di ciptakan. Ide tersebut menyampaikan gambaran struktural yang lebih banyak dari pada yang akan kita terima dari sebagian interaksionis simbolik.

Meskipun ada pandangan struktural demikian, wawasan Goffman yang paling menarik terletak pada ranah interaksi. Dia berargumen bahwa karena orang pada umumnya berusaha menyajikan suatu gambaran diri yang diidealkan didalam sandiwara mereka. ${ }^{9}$

Dramaturgi melihat realitas seperti layaknya sebuah drama, masing-masing aktor berperan dan dan menmpilkan menurut karakter masing-masing manusia berperilaku 
laksana berada di dalam suatu panggung itu, seorang dokter akan menciptakan kesan yang meyakinkan dan mengikuti rutinitas agar dia dianggap seperti dokter. Dalam perspektif media, seperti yang di katakan P.K Manning pendekatan dramaturgi tersebut mempunyai dua pengaruh, pertama ia melihat realitas dan aktor menampilkan dirinya dengan simbol dan penampilan masing-masing media karenanya dilihat sebagai transaksi melalui mana aktor menampilkan dirinya lengkap dengan simbol dan citra yang ingin dihadirkanya. Kedua pendekatan dramaturgi melihat hubungan interaksionis antara khalayak dengan aktor (penampil). Realitas yang karenanya, dilihat dari hasil transaksi antara keduanya.

Dalam pandangan Goffman, ketika seseorang menafsirkan realitas tidak dengan konsepsi yang hampa. Seseorang selalu mengorganisasi peristiwa tiap hari, pengalaman dan realitas yang selalu di organisasi tersebut menjadi realitas yang dialami oleh seseorang pada dasarnya adalah proses pendefinisian situasi. Dalam perspektif Goffman, frame mengklasifikasikan mengorganiasasi dan menginterpretasikan secara aktif pengalaman hidup kita supaya kita bisa memahaminya. Menurut Goffman semua frame adalah sebuah skema interpretasi, dimana gambaran dunia yang dimasuki seseorang diorganisasikan sehingga pengalaman tersebut menjadi punya arti dan bermakna. ${ }^{10}$

Sebagai teori komunikasi sosial drmaturgi memiliki keunikanya sendiri. Keunikan tersbut dapat dilihat dari model teoritisnya yang berbeda dari teori komunikasi sosial mikro lainya. Diantara perbedaan itu adalah mengenai penerapan konsep panggung depan dan panggung belakang, yang selama ini lepas dari pengamatan. ${ }^{11}$

Dalam kaitanya dengan perilaku dramaturgi aktor organisasi kemasyarakatan NahdlatulUlama' dan Muhammadiyah di desa Canga'an kecamatan Kanor kabupaten Bojonegoro, dimana seorang aktor organisasi kemasyarakatan Nahdlatul Ulama' maupun Muhammadiyah di desa Canga'an kecamatan Kanor kabupaten Bojonegoro mampu menunjukkan peran di ruang public Desa Canga'an kecamatan Kanor kabupaten Bojonegoro yang mereka jalani layaknya panggung depan dan ranah domestik organisasi kemasyarakatan sebagai panggung belakang layaknya yang dimaksud Goffman dalam dramaturgi.

\section{METODE PENELITIAN}

Dalam penelitian ini peneliti menggunakan pendekatan kualitatif dengan jenis data deskriptif. Hal ini merupakan metode untuk mengeksplorasi dan memahami makna yang dianggap berasal dari masalah sosial atau kemanusiaan. berfokus pada makna individual dan

\footnotetext{
${ }^{10}$ Deddy Mulyana, Analisis Freaming (Yogyakarta: Lkis, 2002), 81-82.

${ }^{11}$ Nur Syam,Agama Pelacur (Yogyakarta: Lkis, 2010), 175.
} 
menerjemahkan secara keseluruhan akan suatu persoalan. ${ }^{12}$

Dalam penelitian kualitatif ini dibagi menjadi dua jenis data menurut sumbernya yaitu data primer dan data sekunder. Data primer ialah data yang diperoleh secara langsung dari sumber yang diamati. Sedangkan data sekunder yakni data yang dikumpulkan sendiri oleh peneliti dengan menganalisa suatu permasalahan secara lebih rinci dan menyeluruh dengan maksud dapat menjelaskan dan menjawab permasalahan penelitian. ${ }^{13}$ Dalam penelitian ini, peneliti membagi dalam dua macam data tersebut yaitu: 1) Data primer, Dalam penelitian ini merupakan hasil yang diperoleh dari wawancara secara langsung Indah sebagai informan yaitu pengurus ranting Nahdlatul Ulama dan Pengurus ranting Muhammadiyah di desa Canga'an kecamatan Kanor kabupaten Bojonegoro peserta masyarakat umum desa Cangaan anak Kabupaten Bojonegoro dengan data yang dicari peneliti yaitu komunikasi antar aktivis organisasi kemasyarakatan Nahdlatul Ulama' dan Muhammadiyah di desa Canga'an kecamatan Kanor kabupaten Bojonegoro. 2) Data sekunder, Dalam penelitian ini diperoleh dari penjelasan penjelasan teoritis yang berkaitan dengan tema penelitian dengan mengambil dari berbagai referensi pustaka. Keterangan atau pelengkap data sebagai bahan pembanding.

\section{HASIL DAN PEMBAHASAN}

\section{Profil desa Canga'an kecamatan Kanor kabupaten Bojonegoro}

Profil desa merupakan salah satu bagian terpenting dalam sebuah penelitian. Profil desa bertujuan untuk memberikan gambaran serta penjelasan apapun yang terlibat dengan lokasi penelitian. Profil desa ini diperoleh peneliti dari hasil observasi ke kantor desa Canga'an kecamatan Kanor kabupaten Bojonegoro yang berupa buku profil desa. Selain itu peneliti juga menggunakan referensi-referensi yang dianggap peneliti cukup relevan dan mendukung penelitian ini. Dengan adanya profil lokasi penelitian ini hasil penelitian akan lebih mudah untuk difahami.

\section{Mengenal Desa Canga'an}

Desa Canga'an yang letaknya kurang $9 \mathrm{~km}$ dari ibukota kecamatan Kanor atau $5 \mathrm{~km}$ dari kecamatan Sumberrejo memiliki luas tanah kuranglebih 120 ha, $60 \%$ nya berupa lahan sawah pertanian yang sangat subur sekali, sebagian yang lain berupa tanah pekarangan tempat bermukim rumah tinggal penduduk.

\footnotetext{
${ }^{12}$ John W.Creswell, Research Design Pendekatan Kualitatif, Kuantitatif, dan Mixed (Yogyakarta: Pustaka Pelajar, Edisi Ketiga, 2009), 5.

${ }^{13}$ Burhan Bungin, Metodologi Penelitian Sosial (Surabaya: Airlangga University Press, 2001), 129.
} 
Desa Canga'an yang terbentang lebih kurang $2 \mathrm{~km}$ dari arah utara ke selatan dikelilingi desa-desa, disebelah utara adalah Desa Kabalan, disebelah timur adalah desa Tejo dan desa Simbatan, disebelah selatan adalah desa Sarangan. Dulu ditengah desa-desa ini terdapat rawa besar yang dihuni oleh binatang-binatang air dan terhampar tumbuhtumbuhan yang subur nan menghijau merupakan sebuah pemandangan yang sangat indah. Keadaan geografis ini telah dituturkan oleh para kakek- nenek penulis seperti ini memang adanya manakala kita mau mencermati dan mengamatinya.

Adapun disebelah barat diseberang Bengawan solo, terdapat desa Kenongo Sari yang menurut cerita didesa ini dulu tumbuh banyak pohon-pohon besar yang sangat rindang dan teduh, diantara pohon-pohon besar tersebut yang terbanyak adalah pohon "bunga kenanga". Pohon bunga kenanga merupakan pohon yang berukuran besar, dan sering dihinggapi oleh berbagai macam burung, terutama yang banyak berdiam dan bertengger diatas pohon adalah burung-burung molek berleher panjang, berbulu putih gelap berkilauan, itulah yang dinamakan burung "cangak" dan orang-orang sempat menyebutnya "cangak ulo".

Burung-burung cangak atau cangak ulo inilah yang setiap pagi dan sore hari berbondong-bondong berdatangan ke rawa-rawa untuk mencari makan dan minum, setelah semua terpenuhi burung-burung itu kembali ke tempat aslinya diatas pohon-pohon besar yang ada didesa seberang tadi yaitu desa Kenongo sari yang letaknya hanya terpisah oleh Bengawan solo.

Kehadiran ribuan burung-burung cangak atau cangak ulo ditempat rawa-rawa itulah yang mengilhami para penduduk setempat untuk memberikan kepada desa mereka, dengan nama “Canga'an”. Maka terkenalah nama Canga' an sebagai nama sebuah desa yang dimasa tertentu pernah mengenyam masa kejayaanya dan keemasanya.

Canga'an sebgai desa kecil, terletak di pinggiran bengawan solo, satu-satunya desa yang pada masa itu paling banyak dikunjungi dan didatangi oleh orang-orang dari berbagai daerah, dari berbagai kabupaten, dan provinsi bahkan dari manca Negara seperti dari Belanda, Spanyol, Belgia dan Jerman untuk urusan perdagangan tembakau krosok cerutu.

Sebagai nama sebuah desa, Canga'an seperti halnya desa-desa lain, memiliki beberapa dukuhan. Dukuhan-dukuhan tersebut berperan aktif dalam membantu terselenggaranya roda pemerintahan agar dapat berjalan dengan lancar dan baik. Beberapa dukuhan yang terkenal hingga saat ini, ada tiga dukuhan yaitu dukuhan Mejuwet letaknya disebelah utara, dukuhan Berek letaknya disebelah selatan serta dukuhan Jetis letaknya diujung paling timur sebagai palang pintu untuk masuk ke desa Canga'an dari arah selatan 
dan timur.

Disinilah, di dukuhan jetis ini konon dulu para hartawan desa Canga'an membuat benteng perlindungan dan pengamanan secara gaib. Konon sebuah tumbal telah ditanam di dukuhan ini untuk menangkal atas masuknya para penjahat dan perampokan yang bermaksud dan bertujuan tidak baik terhadap penduduk desa.

Satu kisah pernah dituturkan oleh orang-orang tua, oleh kakek-nenek, bahwa pada suatu hari ada segerombolah laki-laki tak dikenal duduk-duduk lesehan di pinggir sawah, pada bagian tangan, kaki dan dadanya dijumpai banyak goresan-goresan karena lecet bekas berdarah. Orang-orang tersebut mengeluh karena tidak bisa pergi keluar dari tempat itu, setelah diketahui banyak orang maka peristiwa itu diberitahukan kepada tokoh di Desa Canga'an. Hasilnya mereka akhirnya dibolehkan dan dipersilahkan pulang.

Sebelum pulang, berceritalah mereka kepada banyak orang kalau semalaman mereka bermaksud untuk melakukan perampokan pada orang-orang kaya di desa Canga'an, namun, sesampainya mereka berada di Dukuhan Jetis tepatnya dipalang pintu masuk desa Canga'an, mereka tidak menemukan daratan sedikitpun kecuali hamparan air seperti lautan atau luapan banjir sebuah bengawan, yang menggenangi berpuluh-puluh hektar sawah dan mereka telah terhalang luapan air itu, daratan yang dikira sebagai hamparan air yang menggenangi hamparan sawah sekian luas itu telah mereka renangi dimalam hari hingga sampai pagi.

Pengalaman seperti itulah yang membuat para perampok itu menjadi jera, sehingga desa-desa di masa dulu selalu aman tentram, penduduknya hidup rukun dan damai, rizkinya dibarokahi, gemah ripah loh jinawi, tak kurang sandang, tak kurang papan dan pangan serta jauh dari segala bentuk kejahatan.

Sebutan nama Canga'an sebetulnya tertuju untuk daerah-daerah yang letaknya dulu berada disekitar rawa-rawa atau tempat-tempat tidak jauh dari situ, tepatnya diantara dukuhan Mejuwet dan dukuhan Berek, sebagian masyarakat menyebutnya dengan "gedongan", hal tersebut mungkin Karena disekitar tempat itu banyak bangunan rumahrumah besar atau rumah-rumah gedong yang hingga saat ini masih banyak bekas-bekasnya.

Di desa Canga'an dulu terdapat tidak kurang dari 200 buah rumah-rumah besar berukuran lebih kurang $11 \mathrm{~m} \mathrm{X} 17 \mathrm{~m}$ terdiri dari rangka kayu jati bentuk bucu dan doro kepek, selain rumah-rumah besar juga terdapat bangunan-bangunan gudang tembakau yang terletak dipinggiran bengawan solo, semua itu sekarang sudah banyak yang musnah, tiggal 
beberapabangunan yang masih bisa dilestarikan biar bisa menjadi saksi sejarah. ${ }^{14}$

\section{Kondisi Geografis Desa Canga'an}

Wilayah desa Canga'an merupakan dataran rendah, sebelah barat langsung berbatasan dengan Bengawan solo, sehingga pada musim hujan serin terjadi banjir genangan, hampir sekitar 75\% kawasan desa Canga'an menjadi terdampak banjir akibat luapan air dari bengawan solo tersebut, baik kawasan pemukiman maupun kawasan pertanian. Akses sarana transportasi menuju ke desa bisa menggunakan roda dua atau lebih, namun pada saat terjadi genangan air dimusim penghujan yang mengakibatkan banjir bisa di tempuh menggunakan perahu untuk kawasan yang terdampak, sedang untuk wilayah yang tidak terdampak bisa ditempuh menggunakan roda dua atau lebih.

\section{Demografi Desa Canga'an}

Dari segi kependudukan, desa Canga'an merupakan desa yang gemuk karena dihuni oleh dua ribu lebih penduduk yang sangat dinamis dalam kehidupan sehari-hari. Sifat gotong royong dan tolong menolong orang-orang desa sangatlah kuat, termasuk masyarakat desa Canga'an kecamatan Kanor kabupaten Bojonegoro. Sifat-sifat kebersamaan seperti ini telah mendorong timbulnya suatu keinginan untuk selalu hidup berdampingan, selalu bermusyawarah dalam memecahkan dalam memecahkan berbagai persoalan. Dari lurah berganti lurah pembangunan desa semakin di tingkatkan, jalan-jalan di permulus menghilangkan becek di musim hujan, sehingga orang-orang desa semakin senang dan para tamu semakin kerasan singgah di desa Canga'an.

Penduduk desa Canga'an memiliki mata pencaarian yang cukup beragam, namun tetap di dominasi kaum petani dannelayan karena memang secara geografis sangat memungkinkan masyarakat desa Canga'an untuk bercocok tanam dan memburu hasil dari perairan sengai bengawan solo. Hal tersebut di ketahui peneliti dari buku profil desa Canga'an kecamatan Kanor kabupaten Bojonegoro pada saat peneliti berkunjung ke kantor desa Canga'an.

\section{Sarana dan Prasarana}

Untuk menunjang mutu suatu masyarakat tentu di perlukan sarana dan prasarana yang menunjang masyarakat untuk meningkatkan kualitas hidup suatu masyarakat. Desa

${ }^{14}$ Sururi Djufri, Sejarah Desa Canga'an (Jakarta: Lembaga Suluh Nusantara, 2005), 3-10 
Canga'an kecamatan Kanor kabupaten Bojonegoro termasuk desa yang antusias untuk menunjang sarana dan prasarana yang ada di desa Canga'an kecamatan Kanor kabupaten Bojonegoro, hal itu dibuktikan dengan masifnya pembangunan-pembangunan yang di lakukan oleh pemerintah desa Canga'an kecamatan Kanor kabupaten Bojonegoro. Mulai dari fasilitas untuk menunjang pendidikan hingga fasilitas tempat peribadatan sangat gencar di laksanakan perbaikan, perawatan hingga pembangunan, pembangunan yang di motori oleh pemerintah desa Canga'an kecamatan Kanor kabupaten Bojonegoro bersama segenap jajaran masyarakat ini terbilang sukses.

Sebab saat ini peningkatan sarana dan prasarana tersebut sudah terlihat nyata, seperti yang bisa kita lihat saat kita berkeliling di desa Canga'an kecamatan Kanor kabupaten Bojonegoro di setiap penjuru terlihat fasilitas-fasilitas yang menunjang seperti masjidmasjid sebagai tempat peribadatan hingga gedung-gedung sekolah, mulai sekolah dasar hingga sekolah tingkat menengah. Hal tersebut merupakan bukti nyata bahwa pemerintah desa Canga'an kecamatan Knaor kabupaten Bojonegoro bersama jajaran masyarakat melalui organisasi kemasyarkatan sangat serius dalam meningkatkan sarana dan prasarana.

\section{Masjid Jami’ Nurul Huda}

Pembangunan masjid tertua di kabupaten Bojonegoro ini bermula dari Buyut Tibah, seorang pedagang serta penyuluh ajaran agama Islam pada masyarakat, mempunyai menantu Ki Wiroyudo atau Kiai Rowudo alias Kiai Suluk, seorang pemuda terampil, dinamis, penuh idealis, serta punya dedikasi yang tinggi teradap lingkungan masyarakatnya. Ki Wiroudo sebagai sosok seorang pemuda yang setiap saat dapat di ajak bicara hal-ihwal yang berkenaan dengan perjuaangan, baik yang berkenaan dengan urusan ekonomi, kemasyarakatan maupun keagamaan.

Kehadiran Buyut Ki Wiroyudo di tengah Buyut Ki Tibah, paling tidak telah memberikan dukungan secara moral dan material atas terealisasinya kemajuan di segala bidang, khususnya yang berkaitan dengan kemajuan keagamaan yang sejak lama telah telah di perjuangkan bersama Buyut Kiai Tibah dan Buyut Kiai Setro Sukun.

Dalam hidupnya Buyut Kiai Tibah maupun Kiai Setro Sukun telah banyak melahirkan keturunan yang menambah semarak dan ramainya suasana keluarga, hidup saling berdampingan sesama keluarga, dan membangun rumah tangga dengan sesama keluarga, dari mereka kemudian lahir putra putri baru yaitu suatu masyarakat desa Canga'an yang berada di pinggiran sungai bengawan solo. Dari mereka lahirlah lagi putra putri yang nantinya tersebar di mana-mana menjadi putra putri bangsa. 
Masyarakat desa Canga'an kian lama semakin bertambah banyak dan seiring dengan itu bertambah banyak pula kebutuhan hidupnya. Untuk menunjang dan memenuhi kebutuan hidup, masyarakat kemuadian membuka lahan pertanian untuk ditanami padi, di samping di tingkatkanya sarana dan prasarana perdagangan, di bangunlah juga pusat-pusat perbelanjaan berupa pertokoan, pasar dan lainya, itu semua yang menjadikandesa Canga'an semakin ramai di kunjungi oleh banyak orang.

Pengaruh relasi pergaulan dengan para pedagang khususnya para pedagang dari daerah Gresik yang kebanyakan telah memeluk agama Islam telah memberikan motivasi yang besar bagi perkembangan jiwa mereka, sehingga bukan saja meraka giat dan memperhatikan membangun sarana fisik duniawiyah, tetapi juga masalah keagamaan. Maka tidak lama setelah menjadi menantu Buyut Kiai Tibah, dengan adanya dukungan sanak keluarga dan masyarakat untuk membangun sebuah rumah ibadah maka tidak lama berdirilah sebuah masjid yang letaknya tidak jauh dari tempat tinggalnya. Masjid ini berukuran 10 (sepuluh) meter X 11 (sebelas) meter, tinggi 7,5 (tujuh setengah) meter, terdiri dari rangka kayu jati yang di ambilkan dari hutan di selatan desa Sumberrejo .

Pada permulaan berdirinya masjid ini masih beratapkan daun ilalang kering yang di susun rapi, kemudian kayu jati keadaan yang sedemikian ini konon berjalan hingga selama 50 tahun. Pada masa-masa pendirian masjid inilah nama Kiai Wiroyudo atau Kiai Roduwo yang di orbitkan oleh Kiai Tibah (mertuanya) untuk memprakarsai, mempelopori berdirinya masjid semakin terkenal. Pada saat usianya relatif masih muda dengan di bantu oleh mertuanya bisa menghimpun masyarakat untuk gotong royong membangun sebuah tempat ibadah yang berupa masjid. Tepatlah kata orang-orang tua dulu bahwa masjid Jami' Nurul Huda desa Canga'an kecamatan Kanor kabupaten Bojonegoro berdiri tahun 1775 masehi. Buyut Ki Wiroyudo bisa menikmatinya bersama-sama masyarakat ingga datanglah ajalnya pada usianya kurang lebih 116 tahun dan di makamkan di sebuah makam yang bernama kramat Mojo.

\section{Komunikasi Antar Aktivis Organisasi Kemasyarakatan Nahdlatul Ulama' dan Muhammadiyah}

Bagi desa Canga'an, memiliki oganisasi Nahdlatul Ulama' dan Muhammadiyah tentu sangatlah menguntungkan. Nahdlatul Ulama' dan Muhammadiyah telah memberikan kontribusi yang sangat baik didalam dukunganya terhadap interaksi sosial. Terdapat dua langkah yang berbeda, akan tetapi keduanya tetap berada dalam satu visi besar. Yakni kemaslahatan umat. Hal seperti inilah yang membuat masyarakat semakin dinamis, dan 
kedepanya tentu akan tetap memainkan peran strategis didalam menjaga interaksi sosial.

Kedepanya peran NahdlatulUlama' dan Muhammadiyah untuk akan tetap diperlukan. Keduanya akan tetap menjadi pilar penyangga dengan cara dan variasiya yang jitu. Selain gaya berorganisasi NahdlatulUlama' dan Muhammadiyah yang cukup menyita perhatian masyarakat, komunikasi di dalam tubuh masyarakat desa Canga'an juga menjadi hal yang sangat layak di perbincangkan.

\section{Munculnya Komunikasi Antar Aktivis Organisasi Kemasyarakatan Nahdlatl Ulama' dan Muammadiyah di Desa Canga'an Kecamatan Kanor kabupaten Bojonegoro}

Desa Canga'an kecamatan Kanor kabupaten Bojonegoro merupakan desa yang sangat dinamis dalam komunikasi sosial, terkhusus jika menyentuh ranah organisasi kemasyarakatan. Dua organisasi kemasyarakatan yang menjadi ruh besar desa Canga'an kecamatan Kanor kabupaten Bojonegoro sangat banyak berbuat dalam pola komunikasi yang terbangun hingga menimbulkan persaingan yang meyangkut kedua organisasi kemasyarakatan tersebut. Di desa Canga'an persaingan yang terjadi antar kelompok maupun perseorangan atas nama organisasi kemasyarakatan sudah lama terjadi, dan ini menjadi makanan bagimasyarkat ketika menemui momen-momen tertentu. Dari pemaparan bapak Nur Syahid dapat kita tangkap bahwasanya faktor sejarah juga ikut mempengaruhi pola komunikasi di desa Canga'an kecamatan Kanor kabupaten Bojonegoro. Desa Canga'an sebagai desa yang kental akan sejarah keagamaan yang di buktikan dengan peninggalan-peninggalan melatar belakangi tradisi keagamaan yang kuat hingga akhirnya Muhammadiyah dan NahdlatulUlama' muncul di desa Canga'an kecamatan Kanor kabupaten Bojonegoro, hingga akhirnya dua organisasi kemasyarakatan ini sama-sama menjadi besar di desa Canga'an kecamatan Kanor kabupaten Bojonegoro dan memiliki banyak kekuatan massa, hingga akhirnya banyak ego-ego yang mulai bermunculan dalam suatu persaingan, inilah salah satu hal yang melatar belakangi komunikasi antar aktivis organisasi kemasyarakatan mulai terlihat di desa Canga'an kecamatan Kanor kabupaten Bojonegoro.

\section{Analisis Teori dengan Fenomena}

Dari berbagai macam pernyataan yang di peroleh peneliti dari informan, teori dramaturgi sangat tajam ketika digunakan untuk menganalisis komunikasi antar aktivis organisasi kemasyarakatan NahdlatulUlama' dan Muhammadiyah di desa Canga'an kecamatan Kanor kabupaten Bojonegoro. Pada dasarnya eksistensi organisasi 
kemasayarakatan NahdlatulUlama' dan Muhammadiyah menjadi harga mahal bagi aktoraktor atau dalam temuan dari informan di atas bisa di sebut Jam 'iyah dari NahdaltulUlama' ataupun Muhammadiyah di desa Canga'an kecamatan Kanor kabupaten Bojonegoro. Banyak faktor yang menyebabkan komunikasi antar aktivis organisasi di desa Canga'an kecamatan Kanor kabupaten Bojonegoro ini terjadi secara otomatis, salah satunya yakni faktor sejarah, di mana desa Canga'an kecamatan Kanorkabupaten Bojonegoro ini merupakan desa yang kental akan sejarah keagamaan, secara turun temurun tradisi keagamaan ini tetap lestari hingga akhirnya NahdlatulUlama' dan Muhammadiyah muncul di desa Canga'an kecamatan Kanor kabupaten Bojonegoro dan mengadopsi tradisi keagamaan dan di komparasikan dengan tradisi Ke-NahdlatulUlama'-an dan KeMuhammadiyah-an yang di bawa organisasi kemasyarakatan tersebut.

Seiring waktu berjalan, karena seringnya ada perbedaan di dalam satu obyek (masyarakat desa Canga'an kecamatan Kanor kabupaten Bojonegoro) komunikasi antar aktivis antara organisasi kemasyarakatan NahdlatulUlama' dan Muhammadiyah pun muncul dan membuat suatu arus sosial di kalangan NahdlatulUlama' dan Muhammadiyah di desa Canga'an kecamatan Kanor kabupaten Bojonegoro, arus sosial inilah yang membuat masyarakat merasa lebih kuat dari kehidupan sehari-harinya akibat dari dorongan organisasi kemasyarakatan NahdaltulUlama' dan Muhammadiyah.

Contoh kecilnya ialah seorang aktor organisasi kemasyarakatan memiliki kekuatan lebih ketika mendapat dukungan dari organisasi kemasyarakatan NahdlatulUlama' maupun Muhammadiyah dalam suatu proses komunkasi yang terjadi di desa Canga'an, katakanlah dalam pemilihan kepala desa, seorang calon memiliki panggung depan yang sangat kuat akibat hal yang di timbulkan dari dukungan organisasi kemasyrakatan, akan tetapi di panggung belakang ketika dukungan organisasi kemasyarakatan tadi terlepas seorang aktor tersebut secara otomastis tidak memiliki kekuatan sosial yang di timbulkan dari dukungan organisasi kemasyarakatan tersebut.

Selain itu, panggung depan (front stage) dalam komunikasi di desa Canga'an kecamatan Kanor kabupaten Bojonegoro juga terlihat saat adanya ruang publik di desa Canga'an kecamatan Kanor kabupaten Bojonegoro, dimana dalam suatu ruang publik tersebut para aktororganisasi kemasyarakatan Nahdlatul Ulama' dan Muhammadiyah bertemu. Yang ditampakkan oleh kedua organisasi kemasyarakatan terebut ialah panggung depan yang baik-baik saja dengan tetap menjunjung tinggi nilai-nilai moral dalam bermasyarakat. Sebaliknya, di paggung belakang (back stage) atau ketika berada diranah domestik organisasi kemasyarakatan baik Nahdlatul Ulama' ataupun Muhammadiyah, dua 
organisasi kemasayarakatan ini kembali berkegiatan serta merumuskan formulasi-formulasi yang kaitanya dengan keberlangsungan berjalanya masing-masing organisasi kemasyarakatan.

Jika penjelasan diatas peneliti analisa sangat relevan dengan teori dramaturgi Erving Goffman karena pada dasarnya Goffman melihat persamaan-persaman antara pertunjukan teater dengan jenis tindakan yang kita jalankan sehari-hari dalam berkomunikasi dipandang sangat rentan yang hanya bisa di jaga oleh pertunjukan dilihat sebagai ancaman besar bagi komunikasi sosial yang sebagaimana terjadi pada pertunjukan teater, goffman membagi dua didalam teorinya dramaturgi antara panggung depan fronstage dan panggung belakang backstage, dimana panggung depan adalah palsu dari sang pelaku sedangkan panggung belakang adalah sifat asli dari sang pelaku.

Dengan muka panggung dalam pertunjukan teater aktor di panggung dan di dalam kehidupan nyata sosial dipandang tertarik pada penampilan kostum yang dipakai dan benda yang digunakan lebih jauh lagi keduanya memiliki wilayah belakang tempat dimana aktor bisa beristirahat untuk mempersiapkan diri untuk sebelum pertunjukan belakang panggung atau luar panggung dalam istilah teater adalah ruang bagi aktor dapat meninggalkan peran mereka dan menjadi diri mereka sendiri.

Analisis dramaturgi ini jelas konsisten dengan akar interaksionalisme simbolis ia berpusat pada aktor tindakan dan interaksionalisme bekerja pada arenayang sama, Gorffman menemukan metafora cerdas dalam teater dan memberikan pemahaman baru terhadap proses-proseskomunikasi skala kecil.

Dari teori dramaturgi analisa penting dalam teori ini adalah kaitanya dengan temuan yang diperoleh dan teori ini yang dikomparasikan dengan komunikasi antar aktivis organisasikemasyarakatan NahdlatulUlama' dan Muhammadiyah di desa Canga'an kecamatan Kanor kabupaten Bojonegoro, dimana dalam komunikasi, aktor-aktor organisasi masyarakat NahdlatulUlama' maupun Muhammadiyah mereka bisa berbuat banyak untuk desa Canga'an kecamatan Kanor kabupaten Bojonegoro karena dukungan organisasi kemasyarakatan NahdlatulUlama' ataupun Muhammadiyah, itu merupakan panggung depan aktor, namun dibalik itu atau di panggung belakang para aktor ketika menjalani komunikasi bersama keluarga atau di ruang sosial di mana tidak melekatnya dukungan dari organisasi kemasyarakatan NahdlatulUlama' maupun Muhammadiyah, para aktor tadi tidak memiliki power sebesar ketika mendapat dukungan dari organisasi kemasyarakatan NahdlatulUlama' atau Muhammadiyah.

Sebenarnya masih banyak faktor lain yang melatar belakangi komunikasi ini terjadi 
di desa Canga'an kecamatan Kanor kabupaten Bojonegoro, akan tetapi muara dari terjadinya pola komunikasi ini tetap tidak jauh dari kedua organisasi kemasyarakatan NahdlatulUlama' dan Muhammadiyah yang memiliki perbedaan dalam visi dan berada dalam satu obyek yakni komunikasi desa Canga'an kecamatan Kanor kabupaten Bojonegoro.

\section{E. SIMPULAN}

1) Munculnya komunikasi antar aktivis organisasi kemasyarakatan NahdlatulUlama' dan Muhammadiyah di desa Canga'an kecamatan Kanor kabupaten Bojonegoro bukan tanpa sebab, beberapa hal yang melatar belakangi komunikasi antar aktivis organisasi kemasyarakatan NahdlatulUlama' dan Muhammadiyah di desa Canga'an kecamatan Kanor kabupaten Bojonegoro yakni faktor sejarah. Sebab, orang yang pertama kali singgah di desa Canga'an kecamatan Kanor kabupaten Bojonegoro yakni kiai Wiroyudho, seorang Kiai yang meninggalkan bangunan berupa masjid tertua di kabupaten Bojonegoro. Selain itu, faktor ego sosial yang terorganisir di dalam organisasi kemasyarakatan NahdlatulUlama'danMuhammadiyah juga mendorong terjadinya komunikasi antar aktivis organisasi kemasyarakatan NahdlatulUlama' dan Muhammadiyah di desa Canga'an kecamatan Kanor kabupaten Bojonegoro. Rasa memiliki terhadap organisasi kemasyarakatan dan desa inilah yang tak bisa terpisahkan. Karena memang ujung tombak desa Canga'an kecamatan Kanor kabupaten Bojonegoro ialah para kader-kader terbaik dari organisasi kemasyarakatan NahdlatulUlama' dan Muhammadiyah. 2) komunikasi antar aktivis organisasi di desa Canga'an kecamatan Kanor kabupaten Bojonegoro bisa dikatakan baik, hal tersebut bisa dilihat dari hubungan kemasyarakatan dan pola komunikasi yang dijalani masyarakat dalam keseharianya. Komunikasi sosial yang baik ialah komunikasi yang dinamis, itu yang menjadi tolak ukur peneliti dalam menilai komunikasi antar pribadi.

\section{Daftar Pustaka}

Arikunto, Suharsimi.Prosedur Penelitian: Suatu Pendekatan Praktek. Jakarta: Rineka Cipta, 2006.

Asshiddiqie,Jimly. Perkembangan dan KonsolidasiLembaga Negara Pasca-Reformasi, Jakarta :Konstitusi Press,2006

Bungin, Burhan.Metodologi Penelitian Sosial. Surabaya: Airlangga University Press, 2001. Creswell, John W.Research Design Pendekatan Kualitatif, Kuantitatif, dan Mixed. Yogyakarta: Pustaka Pelajar, Edisi Ketiga, 2009.

Djufri, Sururi, Sejarah Desa Canga'an. Jakarta: Lembaga Suluh Nusantara, 2005. 
Effendi, Djohan. Pembaruan Tampa Membongkar Tradis: Wacana Keagamaan di Kalangan Muda NU Masa Kepemimpinan Gus Dur. Jakarta: Kompas, 2010.

Fedyani Saefudin, Achmad. Konflik dan Integrasi: Perbedaan Faham dalam Agama Islam. Jakarta: CV Rajawali, 1986

http://mediaindonesia.com/read/detail/122778-kontestasi-politik.

Koentjaraningrat. Masalah-masalah pembangunan. Jakarta: LP3ES, 1982.

Mulyana, Deddy. Analisis Freaming. Yogyakarta: Lkis, 2002

Narbuko, Cholid dan Ahmad, Abu.Metodologi Penelitian.Jakarta: Bumi Aksara, 2003.

Ritzer, George. Teori Sosiologi. Yogyakarta:Pustaka Pelajar, 2012.

Siagian, Sondang P.Filsafat Administrasi.Jakarta : Gunung Agung, 1980.

Soekanto, Soerjono.Sosiologi Suatu Pengantar. Jakarta: RajaGrafindo Persada, 2001.

Sugiyono.Metode Penelitian Kombinasi "Mixed Method". Bandung: Alfabeta, 2011.

Suhartono, Irwan.Metodologi Penelitian Sosial. Bandung: Remaja Rosdakarya, 1996.

Syam, Nur. Agama Pelacur. Yogyakarta: Lkis, 2010

Syam, Nur. Islam Nusantara Berkemajuan: Tantangan dan Upaya Moderasi Agama. Semarang: Fatwa Publishing, 2018.

Syani, Abdul.Sosiologi Skematika, Teori dan Terapan. Jakarta : PT. Bumi Aksara, 2007. Taneko, Soleman B.Struktur dan Proses Sosial. Jakarta: CV. Rajawali, 1984.

Tebba, Soedirman. "Ormas Islam dan Dilema Pembaharuan," dalam IslamIndonesia Menatap Masa Depan. Jakarta: P3M, 1989. 